1 University of

Sherbrooke, Faculty of Medicine and Health

Sciences, Department of Community Health

Sciences, Charles-

LeMoyne Hospital

Research Centre -

Longueuil (QC), Canada.

astrid.brousselle@

usherbrooke.ca

2 University of

Sherbrooke, Faculty of

Medicine and Health

Sciences, Department

of Community Health

Sciences, Charles-

LeMoyne Hospital

Research Centre -

Longueuil (QC), Canada.

samantha.gontijo.guerra@

usherbrooke.ca

\section{Public health for a sustainable future: the need for an engaged ecosocial approach}

\author{
Saúde pública por um futuro sustentável: a necessidade de uma \\ abordagem ecossocial comprometida
}

Astrid Brousselle', Samantha Gontijo Guerra²

\begin{abstract}
The way in which we have structured our societies has made possible major advances in population health. However, this model, based on intensive exploitation of natural resources, is now the source of the greatest threats to human health. Today's environmental issues call for bringing to public health an ecological approach whose actions address not only population health, but also ecological, social, and economic changes - i.e., an ecosocial approach to health. Here we examine the implications, for public health action, of adopting such an approach.
\end{abstract}

KEYWORDS Ecological impact. Public health. Sustainable development indicators.

RESUMO O modo como nossas sociedades foram estruturadas nos permitiu ganhos notáveis em termos de saúde das populações. Contudo, este se baseia em um modelo alicerçado na exploração intensa dos recursos naturais e que é hoje a fonte de uma das maiores ameaças à saúde humana. As questões ambientais atuais clamam pelo investimento de uma abordagem ecológica em saúde pública cuja ação abrange tanto a saúde das populações quanto as mudanças ecológicas, sociais e econômicas, em outras palavras, uma abordagem ecossocial da saúde. Nós veremos neste artigo as implicações da adoção de uma tal abordagem sobre ações em saúde pública.

PALAVRAS-CHAVE Impacto ecológico. Saúde pública. Indicadores de desenvolvimento sustentável. 


\section{Introduction}

The way in which we have structured our societies has made possible major advances for the human species: in the past half-century, the global population has more than doubled (UNITED NATIONS, 2015), we have gained 20 years in life expectancy, the mortality rate for children under five years has fallen by $70 \%$, from 214 per 1,000 live births to 59 , and the total number of people living in extreme poverty has gone down by 0.7 billion, while the total population of poor countries has risen by two billion (WHITMEE ET AL., 2015). However, these gains have been accompanied by intensive exploitation of resources. Indeed, we have seen exponential growth in the use of energy and water and increasing use of fertilizers, among other things (WHITMEE ET AL., 2015). We are creating unprecedented pressure on resources: we have reached maximum thresholds for fish stock replenishment, we are seeing a growing loss of forest cover, and water shortages are increasingly common (WHITMEE ET AL., 2015). Carbon dioxide emissions are steadily increasing, and oceans are acidifying. Greenhouse gas concentrations are at their highest level in 800,000 years (WHITMEE ET AL., 2015).

Earth is a large ecosystem made up of oxygen, water, plants, and animals, including the human species. The ecological equilibrium reached among these different elements and species is, today, the primary determinant of human health (NEIRA, 2014; WATTS ET AL., 2015).

The organizational model we have favoured, based on development and economic growth, worked well up to a certain point. However, we did not realize the damage it would wreak on our ecosystem, damage exacerbated by the pressure of a growing population in a closed system. Our human actions have been very effective in advancing growth in sectors such as agriculture, fishing, and natural resources extraction, and might be considered successful according to criteria for productivity, effectiveness, and efficiency, and to have contributed greatly to population health, but ultimately these actions are not sustainable. We have reached the point where the non-sustainability (FITOUsSI, 2013) of our actions is becoming the greatest threat to human health. We are now at a decisive threshold for survival of the human species: either we continue with the same model of development and growth, from which we can expect major negative impacts on the environment (e.g. drought, climatic events, fires, floods), on social peace (e.g. rise in mass migrations, habitat loss, violent conflicts) and ultimately, on human health (WATTS ET AL., 2015), or we need to drastically change how we organize our societies.

\section{The four approaches to public health}

Historically, we can identify four approaches to public health (LANG; RAYNER, 2015). The first is the sanitary-environmental model, in which major gains in health were achieved through urban sanitation, with installation of running water and sewer systems, construction of clean housing etc. The second is the biomedical model, in which a personalized approach to health made it possible to protect individuals and prevent diseases. Immunization and the use of antibiotics are examples of major advances coming out of this tradition, which continues in clinical prevention through a personalized approach to prevention and protection. The third model, the social-behavioural approach, aims to influence behaviours of individual and communities by persuading them to change their beliefs and lifestyles. This approach involves not only making information available, but also implementing measures to foster the adoption of healthy behaviours. Finally, the human development model considers that we can act on health determinants by implementing redistributive policies (EVANS; BARER; MARMOT, 1994; NAVARRO ET AL., 2006). This model recognizes the interconnection of social 
structures and biology, from which it follows that, to have a positive impact on health, inequities must be reduced.

Each of these approaches has, at a given time, dominated public health discourse, and all four continue to co-exist in the conception of public health action. There is, however, a fifth model, still in the emergent phase - the ecological public health model (LANG; RAYNER, 2015). According to this approach, human existence cannot be dissociated from planetary and biological dynamics, and to have an impact on public health we need to accept, understand, and influence the ecological relationships between humans and the natural environment, which is made up not only of resources, but of living entities. This is the approach we must strive to develop today to confront the challenges imposed by economic growth and the nonsustainability of our human activity.

\section{The ecosocial approach, an ecological model}

To understand the pathways that public health action will have to map out, let us take the example of global warming. According to the Lancet/Rockefeller Commission on Health and Climate Change, climate change represents the greatest threat to human health (WATTS ET AL., 2015). WHO's Director responsible for health and the environment has underscored the fact that climate variations have ecological effects on "the air we breathe, the food we eat and the water we drink," and that "we are losing our capacity to sustain human life in good health" (NEIRA, 2014). Watts et al. (2015), in their exhaustive article on climate change, describe the consequences with regard to the environment (climatic events, fish stocks, agriculture) and pollution, and the impacts of these changes on threats to human health. They also highlight the social impacts of these changes as mediators of health (migrations, violent conflicts etc.) (figure 1). They show how industrial production that emits greenhouse gases diminishes our capacity to sustain sectors that are essential to our survival, creates imbalances in the social environment, and ultimately has an adverse impact on various dimensions of human health. 
Figure 1. Impact of greenhouse gases on the environment and on human health

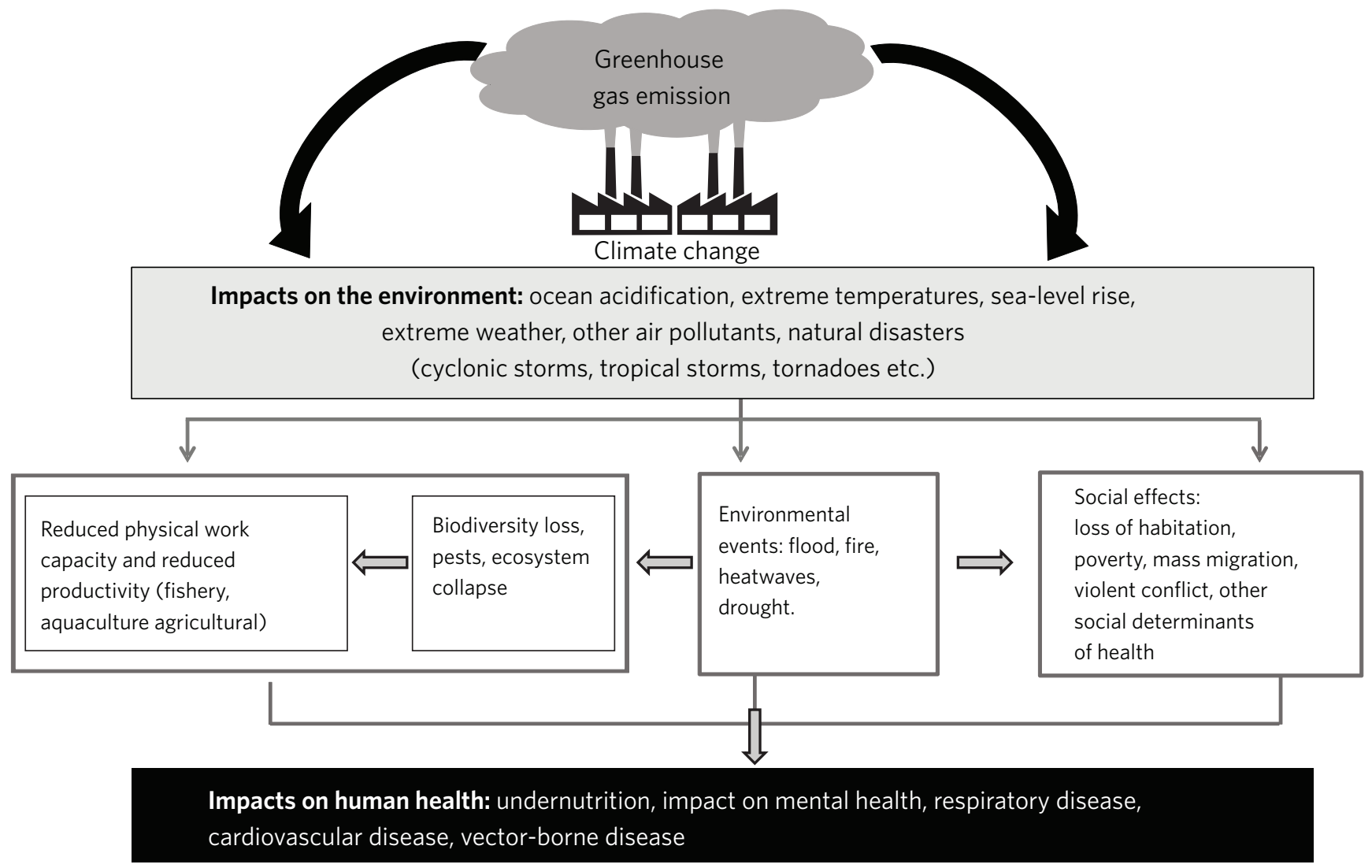

Source: Adapted from Watts et al. (2005)

This figure shows how a human activity - in this case an industry having nothing to do with health - through its emissions produces environmental and social effects that ultimately affect population health. This accumulation of greenhouse gases is now so great that it is becoming a major determining factor in individual and population health, to such an extent that, according to the report of the Commission on Health and Climate Change, it threatens to obliterate all the gains made in global health and development over the past 50 years (WATTS ET AL., 2015).

This new equilibrium - or rather, disequilibrium - requires us to fundamental rethink how we see public health. Public health action must be designed in such a way that it influences the most basic determinants of health - in our case, human activity and its interactions with the environment. While it should, of course, act directly on population health, it should also play a role in social and economic changes and help modify ecological equilibriums in ways that foster a healthsupportive equilibrium. According to this ecosocial approach to health (OSTROM, 2009; LIU ET AL., 2007), public health action is positioned at the intersection of three entities (figure 2): population health, ecological change, and social and economic change (CANADIAN PUBLIC HEALTH ASSOCIATION, 2015). 
Figure 2. An ecosocial framework for public health action

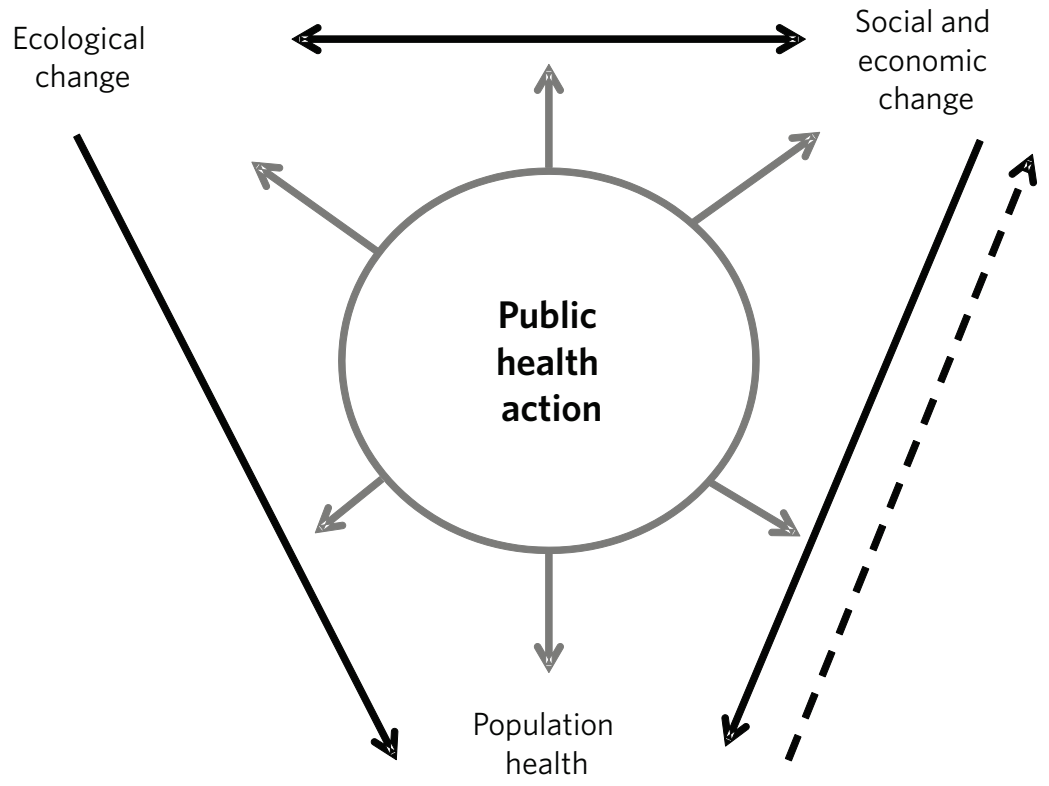

Source: CANADIAN PUBLIC HEALTH ASSOCIATION, 2015, p. 2.

Public health action needs to be fundamentally reassessed, such that population health is understood as being primarily determined by sectors of human activity (agriculture, fishing, transportation, use of natural resources etc.). Its means must also be rethought to foster the social changes needed to implement more sustainable solutions, in order to achieve an ecological equilibrium that will support life for humans and other species in the long term. This is a fundamental change in how public health action should be envisioned, which involves re-investing in sectors that were historically central to this action but that, over time, have been abandoned for a more individualoriented approach.

\section{The implications of an ecosocial approach for public health action}

Adopting an ecosocial approach to public health is a call to fundamentally rethink our way of seeing public health. First, we need to introduce a new value into our discourse. While public health has, for years, militated in favour of health and equity, it must now also take on the sustainability of human actions, and this, in every sphere of human activity, not just those directly targeting health. Sustainability being the primary determinant of human survival and of population health, this must be the prime criterion for public health action when setting priorities, designing interventions, and evaluating those interventions. Introducing this criterion could have consequences on already existing public health programs. Take, for example, Canada's Food Guide. Incorporating the sustainability criterion would involve revising recommendations on protein sources to limit the impact of human consumption on greenhouse gas production and on fish stocks, among other things (LANG, 2015). This conception of public health also calls for analyzing and evaluating not only the direct impacts of interventions, but also the indirect impacts, which Watts et al. (2015) call the co-benefits.

Second, public health action must be 
extended to sectors that do not directly concern health but that can have indirect impacts on health. This means we need to become involved in sectors such as transportation, urban planning, manufacturing, energy consumption etc. Moreover, our action must not be limited to assessing the health impacts of public policies, but must also extend to intervening in the private sector of social and economic activity. We need to fundamentally rethink our ways of acting, of organizing, of producing, of consuming, of transporting ourselves, of communicating etc. This all comes down to imagining better actions, which is, in truth, an ambitious agenda. It is also an agenda that involves redressing the power balances in our society and challenging certain powers gained at others' expense, which is also not an easy thing to do. As some influential groups stand to lose in this restructuring of human activity, the context becomes polarized between those who favour the changes, seeing them as necessary and inevitable, and those who want to maintain the status quo. This polarization will also have consequences for the role to be adopted by public health, which leads us to our third point.

Third, for public health to have a significant influence on transforming the organization of our societies, we need to raise the awareness of actors who are able to play a strategic role in influencing governments, and we must mobilize them to action. The programmatic agenda of an ecosocial approach to public health involves disrupting some balances of power. We know, however, that collaborative-participative approaches have only limited influence in polarized contexts (CONTANDRIOPOULOS ET AL., 2010; CONTANDRIOPOULOS; BROUSSELLE, 2012). As such, if we wish to help shape policies we will need to adopt an 'advocate' role, either alone or in strategic groups, to be able to influence governments (ZAHARIADI, 2014; JENKINS-SMITH ET AL,, 2014).

At a time when the human race, through its activities and its influence on the environment, is building and shaping the elements fundamental to its own survival - water, air, plants, animal species - and modifying the ecological balance to the point where it becomes a threat to this very survival, the pathway laid out by the ecological model of health comes down to adopting an engaged ecosocial approach to public health. Figure 3 summarizes the shift that is needed to move towards an engaged public health approach.

Figure 3. Towards an engaged ecosocial public health
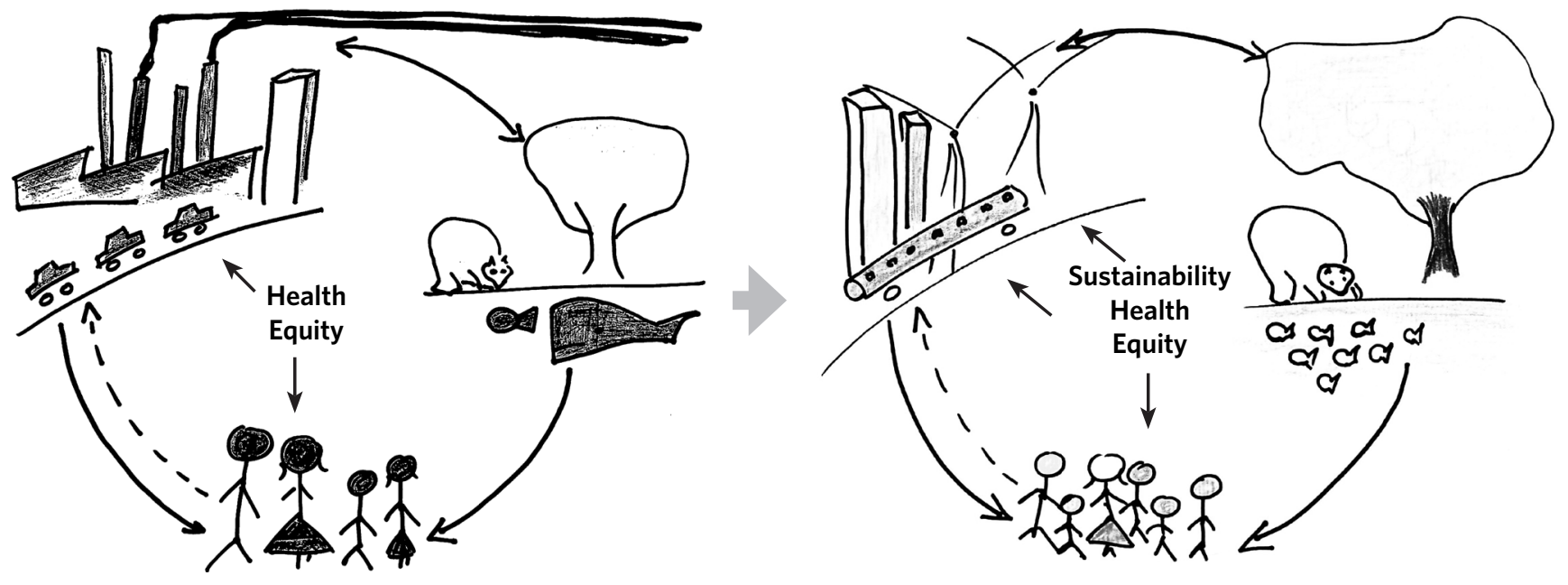


\section{Conclusions}

If we remain content to simply improve on what we are already doing, we are in grave danger of missing the mark. Our ways of working in public health up to now have been inadequate to protect the human species from these ecological changes. We therefore have no choice but to change how we do things. In particular, we need to change how we discern future public health priorities. We can no longer prioritize our actions based on past trends. In fact, we must do quite the opposite, and proactively anticipate action priorities. We need to imagine other ways of organizing our

\section{Referências}

\section{CANADIAN PUBLIC HEALTH ASSOCIATION. \\ Global change and public health: addressing the eco- logical determinants of health. Discussion document. [Internet]. Ottawa, 2015. Available in: <http://www. cpha.ca/uploads/policy/edh-discussion_e.pdf > . Accessed in: 31 jul. 2015}

CONTANDRIOPOULOS, D. et al. Knowledge exchange processes in organizations and policy arenas: a narrative systematic review of the literature. Milbank $Q$, New York, v. 88, n. 4, p. 444-483, dec. 2010

CONTANDRIOPOULOS, D.; BROUSSELLE, A. Evaluation models and evaluation use. Evaluation (Lond), London, v. 18, n. 1, p. 61-77, jan. 2012.

EVANS, R. G.; BARER, M. L.; MARMOT, T. R. Why are some people healthy and others not? Hawthorne, NY: Aldine de Guyter, 1994. societies and of structuring human activity and our cities, and of shaping behaviours. This is, admittedly, an enormous challenge. It will require that we give up certain deeply-ingrained ways of working. We are indeed proposing an ambitious agenda that overturns our traditional conceptions of public health. We can see these new roles as being risky or, at the very least, unsettling. However, today's issues of non-sustainability directly threaten the survival of the human species. We must imagine the world differently, and take the risk of doing things differently - a risk that will still be much less than that of doing nothing by continuing along our current path.
FITOUSSI, J. P. Le théorème du lampadaire. Paris: Édition Les Liens Qui Libèrent, 2013.

JENKINS-SMITH, H. et al. The advocacy coalition framework: foundations, evolution and ongoing research. In: SABATIER, P. A; WEIBLE, C. M. (Org.). Theories of the policy process. Boulder, CO: Westview Press, 2014. p. 183-224.

LANG, T. Sustainable food, nutrition and health. In: EUROPEAN PUBLIC HEALTH ASSOCIATION CONFERENCE. Plenary presentation. Milan, 2015. Available in: $<$ https://ephconference.eu/plenary-session-8>. Accessed in: 13 apr. 2016.

LANG, T., RAYNER, G. Beyond the Golden Era of public health: charting a path from sanitarianism to ecological public health. Public Health, London, v. 129, n. 10, p. 1369-1382, oct. 2015. 
LIU, J. et al. Complexity of coupled human and natural systems, Science, New York, v. 317, n. 5844, p. 1513-1516, sep. 2007.

NAVARRO, V. et al. Politics and health outcomes. The Lancet, Londres, v. 368, n. 9540, p. 1033-1037, sep. 2006.

NEIRA, M. Climate change: an opportunity for public health, commentary. Media Center. World Health Organization, 2014. Available in: <http://www.who. $\mathrm{int} /$ mediacentre/commentaries/climate-change/en/>. Accessed in: 31 jul. 2015.

OSTROM, E. A general framework for analyzing sustainability of social-ecological systems. Science, New York, v. 325, n. 5939, p. 419-422, jul. 2009.

UNITED NATIONS. Department of economic and social affairs. Population division: world population prospects, the 2015 revision, 2015. Available in: <http://

esa.un.org/unpd/wpp/>. Accessed in: 1 dez. 2015.

WATTS, N. et al. Health and climate change: policy responses to protect public health. The Lancet, London, v. 386, n. 10006, p. 1861-1914, jun. 2015.

WHITMEE, S. et al. Safeguarding human health in the Anthropocene epoch: report of The Rockefeller Foundation-Lancet Commission on planetary health. The Lancet, London, v. 386, n. 10007, p. 1973-2028, jul. 2015.

ZAHARIADI, N. Ambiguity and multiple streams. In: SABATIER, P. A.; WEIBLE, C. M. (Org.). Theories of the policy process. Boulder, CO: Westview Press, 2014. p. 25-58. 